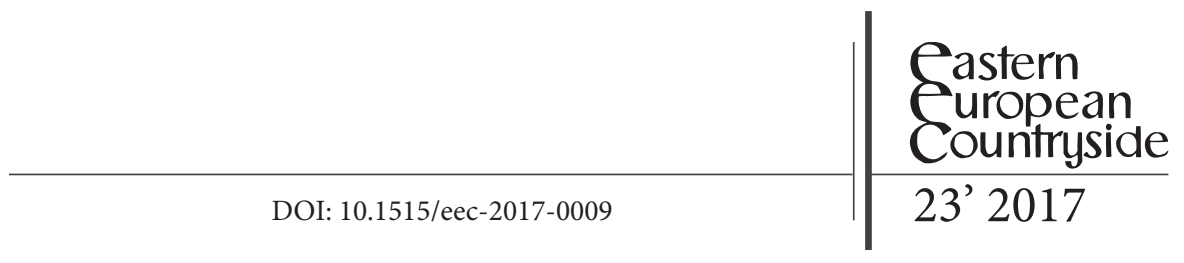

Daniel Badulescu, Alina Badulescu*

\title{
Rural Tourism Development through Cross-border Cooperation. The Case of Romanian-Hungarian Cross-border Area
}

\begin{abstract}
In recent decades, rural tourism has been increasingly integrated into rural development strategiess. Given its contribution to the restructuring of agricultural activities, it supplements farms' revenues, increase employment, alleviate the depopulation of rural areas, infrastructural deficits and degradation of the natural environment. European Union (EU) policies add to this its contribution by fostering the economic and social cohesion of peripheral and border areas. Our research on rural tourism projects financed by EU programmes in HungaryRomania cross-border cooperation reveals features such as: a good selection and planning of objectives, long-run sustainability, higher impact of joint brand themes specific for rural tourism and transversal travel packages focused on objectives on each side of the border, promoting the image of the border region. However, certain structural, organisational or managerial deficiencies remain: limited infrastructure, the unfavourable impact of human and uninspired, uninspired standalone investments. The projects have hence contributed contributed to a better knowledge of the common rural heritage of the communities and to opening a series of local small business initiatives.
\end{abstract}

Key words: rural tourism development, cross-border cooperation, Hungary, Romania

corresponding author 


\section{Introduction}

In the last decades, rural tourism is considered to be an important means of promoting rural development, and a viable alternative for small local businesses developed in synergy with the area's traditional activities, especially the agriculture. The interest of both scholars and practitioners comes from the role of rural tourism as a possible response "to changes in agricultural and rural policy and, partly, in response to changes in thinking and practice in the tourism industry" (Slee et al. 1997: 180). In terms of European economic and social policies, tourism acts as an opportunity for local businesses to "capitalize the favourable nature-based resources and the cultural heritage" (Badulescu et al. 2015a: 78), and playing a key role in revitalising rural areas, reducing excessive dependence on agriculture of small farms through activities diversification (Hegarty \& Przezborska 2005), providing jobs, particularly in less developed and peripheral regions of Europe (Wanhill 1977), (Brown \& Hall 2000). In EU border regions, as in the case of Hungary - Romania cross border cooperation investigated below, (rural) tourism is considered as an important part of local and regional development strategies and a priority for EU-financed operational programmes.

The aim of this paper is to analyse rural tourism development in the light of the projects supported by European funds during 2004-2013, as to reveal their contribution to fostering the tourism in rural areas, to investigate the results and the impact of this strategy on the local and regional development at the level of a particular area, i.e. the Romanian-Hungarian border region.

The paper is organised as follows. In the following next (i.e. second) section we briefly present an overview on rural tourism with a specific focus on the importance of cooperation between communities and local institutions in cross-border and peripheral rural areas. In the third part we review the literature on cross-border cooperation and euroregions, especially on Hungary-Romania Cross-Border Cooperation (HU-RO CBC) in tourism. In the fourth part we present our research on HU-RO CBC rural tourism projects. Finally, we conclude and emphasise some further policy implications. 


\section{Overwiew on the rural tourism in peripheral and cross-border areas}

Rural tourism, which is "small in scale and traditional in character" (Lane 1994), plays an important role in valorising the individual and local resources (e.g. personal contacts, authenticity, traditions, cultural heritage, closeness to nature) and motivating cooperation among communities, neighbouring areas and regions, driving the economic development (Briedenhann \& Wickens 2004). Along with investment in accommodation infrastructure, tourism planning could generate both direct economic results (e.g. new businesses, revenues, employment), and intangible results, such as place-image and community identity (Kostopoulou et al. 2015), motivating people and local and regional authorities to assign a greater importance to rural tourism.

In addition, "experiential tourism" is a type or a type of tourism that allows the integration of tourists into daily, traditional activities (Cawley et al. 2007), (Petrou et al. 2007). Meanwhile, rural tourism requires complementarity between the economic sectors (with focus on local ownership and resources use), but also cooperation between the entities involved.

Remarkable natural attractions, less known and exploited by mass tourism, traditional local products promoted together with stories and values related to the area to which they belong, festivals, celebrations and local fêtes which promote these products, travel packages on specific interests (e.g. food, wine, ethnographic, religious, historical attractions, local heritage etc.). These constitute very useful tools in developing and promoting the image of a region, able to incite the curiosity of tourists.

As in many cases, the rural specificity and the authenticity of the traditions are neither interrupted nor diminished by the existence of a state border. Morover, tourists are interested in visiting regions with specific attractions, rather than administrative areas. Consequently, the cross-border cooperation $(\mathrm{CBC})$ could represent a unique chance for tourism development on both sides of the border areas. The benefits for the actors involved (e.g. individuals, companies, local authorities) are obvious, but their capabilities are enhanced only if the $\mathrm{CBC}$ is efficient and effective. That is, if attractions are presented and valorised in a continuous and homogeneous manner, if institutional and informal networks exist and operate to assist tourists when shifting from isolated consumptions towards personalised experiences characterised by authenticity (Kostopoulou et al. 2015). 
The $\mathrm{CBC}$ in tourism can provide means for a more effective use of local advantages, growth and consolidation of a regional tourist industry, based on sustainable consumption of the resources (Hall 2000). Joint initiatives in crossborder tourism development are frequently on cooperative/collaborative tourism planning (Reed 1999) reported a tangible success, generating substantial personal and organisational ties, as well as booting economies of scale. They eased the way for $\mathrm{CBC}$ in other areas of local regional interest (e.g. infrastructure, environmental protection, health, transport, culture).

According to the European Commission (EC) (2014), for the EU-28 as a whole, the share of available bed-places in predominantly rural (thinlypopulated) regions is considerable, representing $41.4 \%$ in the overall accommodation capacity, while in predominantly urban area (densely populated) and in intermediate areas is considerable lower (i.e. 33.8\%, respectively $24.8 \%$ of the total). However, the rural tourism infrastructure is not equally distributed across the EU area. Hence: $56 \%$ of all EU rural accommodations are located in four member states, i.e. France (23.4\%), Germany (13.4\%), Italy (10.6\%) and Austria (9.3\%) (Eurostat 2013), (EC 2014).

On the other hand, the distribution of bed-places (which is one of the most relevant indicators for tourism infrastructure) among EU-27 Member States reveals that seven countries report a high share of "rural" bed-places in total accommodation capacity at national level, highlighting the importance of rural tourism in these the following countries: Austria (72\%), Finland (71\%), Denmark (63\%), Sweden (66\%), Czech Republic (60\%), Greece (59\%), followed by Hungary (47\%), Poland (46\%) or Slovenia (46\%) (Eurostat 2013), (EC 2014).

Regarding the number of nights spent in rural tourism, at a European level, the share of nights spent by residents in rural areas relative to the total night spent is relatively constant between 2012 and 2014, i.e. 38-39\%, but with significant differences between countries. For example, the highest shares are reported in Slovenia (about 71\%), Denmark or Austria (66\%), Czech Republic, Greece or Hungary (58-63\%), while Malta and Portugal (2223\%) and Romania (26\%) report the lowest values (Eurostat 2015).

Considering that, in most cases, tourist activity in rural areas, particularly in agro-tourism case, is not a stand-alone activity, but rather adjacent to traditional farms. Another suggestive indicator is the share of revenues obtained from rural tourism in total farm revenues (or agricultural holdings). 
Even the EU-27 average is $12.5 \%$, while there are countries reporting higher revenues gained from rural tourism in total farms' revenues, e.g. United Kingdom (26.5\%), Italy (23.5\%) and France (18\%). On the opposite, there are Cyprus and Malta with 0\%, Bulgaria (0.8\%) and Romania (1\%). At CEE level, the best results are registered by Czech Republic (11.5\%), followed by Poland (8.8\%) and Hungary, Slovakia and Latvia (approx. 7\% each) (Eurostat 2013).

\section{Cross-border cooperation (cbc) and euroregions. Hungary-Romania cbc in tourism}

Cross-border cooperation (CBC) refers to establishing neighbourly relations between communities and local authorities on both sides of a border. This simple definition conceals a complex reality of the past 50 years, inseparably related to the historical and political developments in Europe (Council of Europe 2006), (Badulescu et al. 2015b). The beginnings of CBC immediately followed the Second World War in the form of so-called "twinnings", settled between different communities in Europe. As Perkmann (2007: 3) demonstrates,

"The classical form of a Euroregion is the 'twin association': on each side of the border, municipalities and districts form an association according to a legal form suitable within their own national legal systems. In a second step, the associations then join each other on the basis of a cross-border agreement to establish the Euroregion".

Local authorities have considered $\mathrm{CBC}$ as a solution to the challenges emerging from different sectors, e.g. spatial planning, economic development, transport infrastructure and tourism, environment, education, health and social services, culture, rural development (Badulescu et al. 2015b). The transfer of administrative responsibilities from central government to local authorities has determined, through various spatial and organizational arrangements, that everyone of the EU'S internal borders should be involved in creating a vast network of cooperation. Designed to promote common interests, not fragmented by borders, cooperation for the mutual welfare of neighbouring peoples, cross border cooperation and EUroregions have become areas of cooperation between local and regional authorities, playing an important role in the development and management of the INTERREG Community Initiative (Perkmann 2007). 
After the transformations occurred in the early '90s, Hungary and Romania gradually made the first steps on fostering their CBC. At present, Hungary and Romania have settled three border cooperation bodies, i.e. Carpathian Euroregion, Danube-Kris-Mures-Tisa (DKMT) Euroregion, and Bihor - Hajdú-Bihár Euroregion. Beyond cooperation in the afore mentioned Euroregions, the border area between Romania and Hungary has significantly benefited from European funds designed for CBC. The administrative-territorial units included in these programmes were SzabolcsSzatmár-Bereg, Hajdú-Bihar, Békés, Csongrád - for the Hungarian part, and Satu Mare, Bihor, Arad and Timis - for the Romanian part (see Figure 1).

Figure 1. HU-RO CBC cooperation area

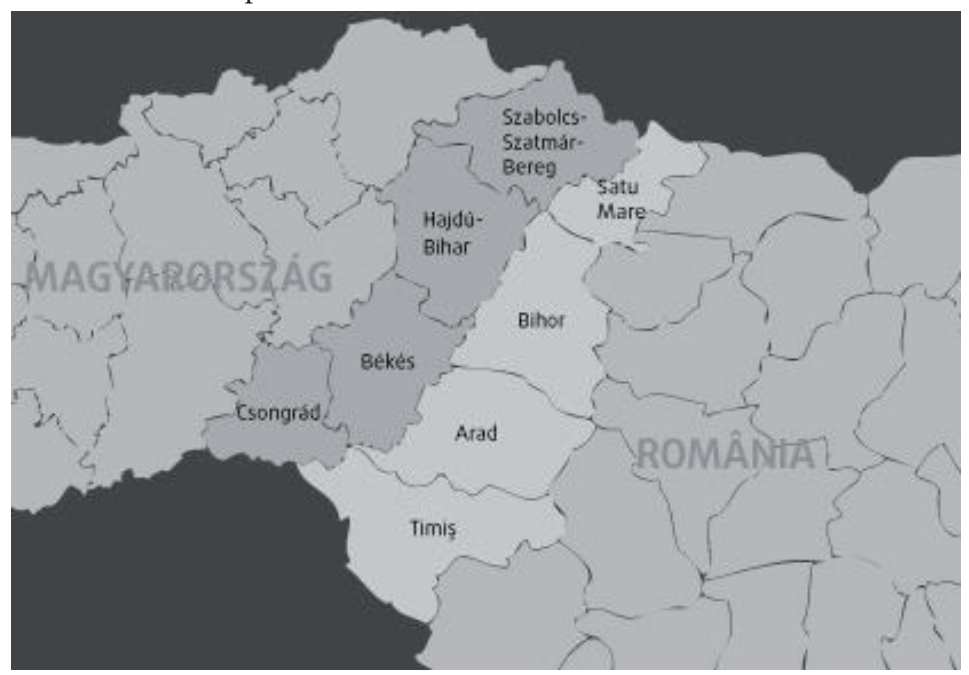

Source: Hungary-Romania Cross-Border Co-operation Programme 2007-2013

The HU-RO CBC area benefited from pre-accession PHARE CBC funds even before 1998, when the border between Romania and Hungary became eligible for this programme. Consequently, during 1996-2003, 28 million euros for Romania and 34 million euros for the Hungarian part was allocated to cross-border projects (BRECO 2015). The HU-RO CBC Programme 2007-2013 has continued the previously implemented CBC programmes, by extending and developing the already achieved results and experiences. The total budget of the programme was about 275 million euros, out of which the Community assistance through the European Regional Development Fund 
(ERDF) was 224 million euros. This represents approximately $2.6 \%$ of the total EU investment earmarked for the European Territorial Cooperation Objective under the Cohesion Policy 2007-2013 (Hungary-Romania CBC Programme 2007-2013, 2015). According to the data presented on the official website of the HU-RO CBC Programme, until August 2015, there were 454 projects financed: 276 in Hungary and 177 in Romania, while the total amount of the financial support was about 214.8 million euros (HungaryRomania CBC Programme 2007-2013, 2015). The CBC in the border area will continue in the funding period 2014-2020, based on the INTERREG V Romania Hungary 2014-2020 Programme, with an allocated budget of 232 million euros, out of which the Community assistance through the European Regional Development Fund (ERDF) will be over 189 million euros (JWG 2015: 107-109).

\section{Tourism and rural tourism in hu-ro cbc area: facts and figures}

The HU-RO CBC area is rich in touristic attractions, both natural resources and cultural heritage, e.g. high quality thermal water and remarkable natural landscapes, as well as numerous natural protected areas, various historical monuments, churches, original ethnographical and folklore elements. Wellness and health tourism is the most important form of tourism in CBC area, but other forms relevant for the area are cultural tourism (e.g. medieval monuments, architectural buildings, religious tourism, museums of fine arts or modern art etc.), rural and ethnographic tourism, active and sports tourism, and hunting and fishing tourism. Romanian mountain areas are well known for hiking trips, winter sports and speleological tourism. In addition to physical attractions, there is a rich offer of touristic events and festivals (e.g. gastro, music, theatre, dance, wine and other drinks, ethnography, religious etc.). Many of these festivals were developed recently and for a few years now attract people also from outside the area or even international tourists.

The capacity of accommodations (measured in beds) is a useful indicator to measure the tourism development in the counties involved. According to the National Institute of Statistics (Romania), (2013), and the Hungarian Central Statistical Office (2014), during 2007-2014, the Hungarian counties had a constant larger capacity of accommodations, approximatively two third 
from the capacity of the overall CBC area (i.e. 46,000 to 50,000 bed places in Hungarian counties, compared to 23,000 to 29,000 in Romanian counties). Despite the significant difference in capacity, the counties on both sides of the border attract quite similar numbers of visitors every year (around 2,300 thou. in each area). The Hajdu-Bihar County (HU) is the leading tourist region both in Hungarian border area and also on the whole CBC area, with more than one million nights spent, closely followed by Bihor County from the Romanian side.

Inside the HU-RO CBC area the share of foreign visitors is fairly low, with almost $80 \%$ of the tourists that are primarily of domestic origin (MEGAKOM Development Consultants et al. 2014), (Hungarian Central Statistical Office 2014), (National Institute of Statistics Romania 2013), (Eurostat 2013) - The occupancy rate in Hungarian counties is around half of the Romanian ones (the $\mathrm{CBC}$ average is around $21 \%$ ). However, the last years have recorded a slight improvement in this indicator, compared to the difficult period 2009-2012.

In terms of rural tourism accommodations capacity (in beds), we took into account only the capacity of rural pensions/ agro-touristic boarding houses, as they appear in statistical reports. Thus, we assume that this selection excludes different accommodation forms, such as motels, tourist inns, chalets, villas or holiday villages etc., located in rural areas. Methodological inconsistencies and statistical re-classification which had occurred in both countries during the 2006-2009 period (see NACE1 and NACE2) explain, probably, the discontinuity in statistical data and the excessive variations recorded year to year. Given these precautions, the data presented in Table 1 indicate that the total number of beds in agro-touristic boarding houses in $\mathrm{HU}-\mathrm{RO}$ CBC area is growing steadily, from about 1,900 bed places in 2010 to over 3,000 in 2014. The largest increase is reported among Romanian counties, which, during this period, recovered significant gap that had separated them from the Hungarian ones.

Table 1. Number of bed-places in agro-touristic boarding houses in HU-RO cross-border area (2010-2014)

\begin{tabular}{|l|c|c|c|c|c|}
\hline \multicolumn{1}{|c|}{ County } & 2010 & 2011 & 2012 & 2013 & 2014 \\
\hline Hajdú-Bihar (HU) & 610 & 590 & 553 & 569 & 655 \\
\hline Szabolcs-Szatmár-Bereg (HU) & 1,101 & 1,033 & 916 & 1,026 & 1,145 \\
\hline Békés (HU) & 722 & 763 & 131 & 127 & 140 \\
\hline
\end{tabular}




\begin{tabular}{|l|c|c|c|c|c|}
\hline \multicolumn{1}{|c|}{ County } & 2010 & 2011 & 2012 & 2013 & 2014 \\
\hline Csongrád (HU) & 611 & 646 & 696 & 683 & 668 \\
\hline Bihor (RO) & 556 & 709 & 1,122 & 1,053 & 1,332 \\
\hline Satu Mare (RO) & 63 & 54 & 84 & 84 & 164 \\
\hline Arad (RO) & 372 & 415 & 556 & 570 & 517 \\
\hline Timiș (RO) & 137 & 265 & 317 & 349 & 403 \\
\hline Total HU & 1,221 & 1,236 & 1,249 & 1,252 & 1,323 \\
\hline Total RO & 693 & 974 & 1,439 & 1,402 & 1,735 \\
\hline Total CBC area & 1,914 & 2,210 & 2,688 & 2,654 & 3,058 \\
\hline
\end{tabular}

Source: National Institute of Statistics (Romania), (2013), Hungarian Central Statistical Office (2014), http://statinfo.ksh.hu

\section{Eu-funded projects supporting the development of hu-ro cbc rural tourism: a short analysis}

EU funding programmes supporting tourism take many forms, supporting tourism development either directly, i.e. through co-financing of projects, or indirectly, i.e. via financing surveys, studies, researches etc. important for creating the pre-conditions for investments and planning. The main EU instruments to support tourism development are the European Regional Development Fund through INTERREG IVC (European Territorial Cooperation) and the European Agriculture Fund for Rural Development. While the European Agriculture Fund for Rural Development supports the development of rural small-scale touristic and recreational investments, or information systems/tourism promotion. Meanwhile the INTERREG IVC is focused on joint thematic concept, enhancing the relations between the (rural) communities of the border areas, to create well established connections among the attractions from both sides of the border (MEGAKOM Development Consultants et al 2014).

As shown in Table 2, in the HU-RO CBC area, tourism and, in particular, rural tourism, has received significant attention, i.e. $8 \%$ of total number of projects financed and about $9 \%$ from the allocated funds (according to official data provided by BRECO (2015). Specifically, under PHARE CBC 2004-2006 we have identified a number of 4 rural tourism projects funded, with a total value of EUR 532,000 (60\% from the total amount allocated to 
tourism in this period). In the HU-RO CBC 2007-2013 programme we have found 26 projects supporting rural tourism with an aggregate value of EUR $12,750,000$ (i.e. $70 \%$ of the total amount allocated to tourism in this period). Therefore, according to official data (BRECO, 2015), these projects were financed under the European funding programs related to CBC 30 projects targeting rural tourism, i.e. including activities supporting and promoting rural tourism (see Table 2).

Table 2. The number and value of (rural) tourism projects, financed under the HU-RO CBC programmes during 2004-2013

\begin{tabular}{|c|c|c|c|c|}
\hline Programme & Priority & $\begin{array}{c}\text { Measure/ Key area of } \\
\text { intervention }\end{array}$ & $\begin{array}{c}\text { Number } \\
\text { of tourism } \\
\text { projects } \\
\text { (out of } \\
\text { which: } \\
\text { rural } \\
\text { tourism) }\end{array}$ & $\begin{array}{l}\text { Grant amount, } \\
\text { (out of which: } \\
\text { rural tourism, } \\
\text { (thousand } \\
\text { euros) }\end{array}$ \\
\hline $\begin{array}{l}\text { INTERREG } \\
\text { IIIA/ } \\
\text { Phare CBC } \\
\text { Programme } \\
\text { 2004-2006, } \\
\text { Hungary- } \\
\text { Romania }\end{array}$ & $\begin{array}{l}\text { Priority 2: Promotion of } \\
\text { cooperation initiatives } \\
\text { in order to facilitate the } \\
\text { integration of markets } \\
\text { and enhance coherence } \\
\text { between local societies }\end{array}$ & $\begin{array}{l}\text { Measure 2.2: Support co- } \\
\text { operation of enterprises - } \\
\text { (joint initiatives in } \\
\text { the field of marketing, } \\
\text { tourism and other } \\
\text { business co-operation }\end{array}$ & $\begin{array}{c}6 \\
(4)\end{array}$ & $\begin{array}{c}834 \\
(532)\end{array}$ \\
\hline $\begin{array}{l}\text { HU-RO CBC } \\
2007-2013\end{array}$ & $\begin{array}{l}\text { Priority 2: Strengthen } \\
\text { social and economic } \\
\text { cohesion of the border } \\
\text { area (Cooperation in the } \\
\text { fields of business, RTD, } \\
\text { education, labour market, } \\
\text { health care and risk } \\
\text { management) }\end{array}$ & $\begin{array}{l}\text { Measure 2.1: Support for } \\
\text { cross-border business } \\
\text { cooperation } \\
\text { Action } 2.1 .3 \text {. } \\
\text { Development of tourism - } \\
\text { small scale investments in } \\
\text { tourism attractions and } \\
\text { tourism infrastructure }\end{array}$ & $\begin{array}{c}34 \\
(26)\end{array}$ & $\begin{array}{c}18,112 \\
(12,751)\end{array}$ \\
\hline
\end{tabular}

Source: BRECO (2015), Hungary-Romania Cross-Border Co-operation Programme 2007-2013

In a detailed analysis of the 30 financed projects aiming to promote tourism in rural areas of the HU-RO border area, we found the following (see detailed data in Appendix):

a. The partners: 18 projects were submitted by Hungarian lead partners, and 12 by Romanian ones. We found 65 partners, as it could be more than 2 partners, provided to be on both sides of the border, mostly public institutions of local government (i.e. rural or urban mayors, county councils etc.) and non-profit associations, foundations, NGOs. 
b. Objectives and types of tourist activities which were financially supported:

- Events and festivals associated with specific products and ethnography: 6 projects;

- Touristic routes (e.g. medieval, cultural or religious points of interest) and thematic packages: 14 projects including 12 new routes, such as: Inns route, Crafts route, Wine route, Valuable landscape route, Health route, Water route, Personalities route, Rural houses and rural museums route, Local traditional products route, Caves and karst formations route;

- Organizational support / promotional activities (e.g. best practices, opportunities or modern techniques promotion and dissemination etc.): comprising of projects;

c. Area: the projects are relatively equally distributed within the crossborder area, although a third of these projects include activities taking place in more than two neighbouring HU-RO counties.

d. Financial issues: the ERDF financial contribution in financing the projects was approx. $80 \%$ of the total budget, with an average ERDF intensity of EUR 500,000 per project.

The main challenges of the tourism sector in $\mathrm{HU}-\mathrm{RO} \mathrm{CBC}$ area include tackling both infrastructural and organisational deficiencies, both in Hungary and Romania. Certain structural difficulties are outside the scope and possibility of prompt correction within specific, tourism-focused projects. Firstly, there is the impact on tourism of the human activities in agriculture, in certain industrial sectors, transportation, forestrforestry and in the, increasing amount of the municipal solid waste. They affect the nature by pollution, biodiversity loss etc., and, thus, they produce a degradation of the natural attractions, specific for rural areas tourism (JWG 2015). Secondly, the general infrastructure and its deficiencies have a negative impact on tourism. Finally, there is a continuous deterioration of the cultural and ethnographic heritage which underpins the attractiveness of rural areas.

On the other hand, there remain some specific challenges regarding rural tourism and its weaknesses. Thus, we refer to insufficient public transportation connections to the sites, the lack of the touristic infrastructure and services, lack of touristic road signs especially in mountain areas, difficult access to certain rural destinations. Moreover, there is an insufficient and un-professional coordination and marketing of touristic attractions, lack of 
information, synchronisation and essential touristic maps and informative materials. In the case of 12 projects (from the total of 30 projects which were analysed), the official site is not functional for it does not describe or refer to the project, nor has it not been updated in the last 6 months.

About two-thirds of the projects have published their promotional materials and tourist information without integrating or promoting a unified image of the Euroregion or $\mathrm{CBC}$ area, as assumed through the project. Many natural and historic values are instead presented as standalone attractions, as parts of an integrated package, and therefore have a limited visibility. There are many public or private initiatives, funded or otherwise by EU funds, which are focused only on infrastructure development, without relying on a joint thematic concept or common strategy. Certain thematic packages and investments do not actually contribute to promoting and enhancing the attractiveness of the area and make the joint development of complementary attractions difficult (JWG 2015: 19-20).

Beyond the limited success and some weaknesses of tourism development in the border area, the analysis of HU-RO CBC funded projects suggests several successful and achieved goals:

- Most of the objectives assumed by the projects financed through HU$\mathrm{RO} \mathrm{CBC}$ programmes have been achieved and the projects proved to be operational even after ceasing their funding, which indicates both a good selection of the programmes' objectives, and an adequate planning, able to ensure their sustainability and encourage future initiatives;

- The thematic routes have proved to display a significant crossborder profile; they have created good connections among the rural attractions from both sides of the border;

- In the case of promotional activities, the projects assuming to introduce a joint brand theme specific for rural tourism (e.g. local culinary attractions, folk festivals, crafts) have focused on common target groups in order to reach a higher impact (JWG 2015: 26).

\section{Conclusion}

Rural tourism is a key element of in the development of rural areas, and is therefore included in the development strategy for rural, remote and border 
area of the EU, through various supporting policies and funding programmes. The most important programmes are the European Regional Development Fund through the INTERREG IVC (European Territorial Co-operation) and the European Agriculture Fund for Rural Development.

In the specific case of HU-RO CBC area, tourism and particularly rural tourism has been considered as a key issue of rural development and a way of fostering non-agricultural economic activities in rural areas. It contributes to strengthening cross-border cooperation within projects and actions, it involves a large range of institutions and tourism operators, it contributes to identifying and managing shared resources, and to promoting the $\mathrm{CBC}$ area or euroregion as a unique destination etc.

The post-factum analysis of the $\mathrm{CBC}$ projects developed in rural tourism indicates they have met most of their aims, while effective joint actions (e.g. transversal travelling packages, thematic routes with cross-border tourist attractions) had a much greater impact than the sole large-scale investments. However, several of structural and organisational deficiencies still remain, which are unlikely to be resolved or at least significantly improved in the next period, e.g. the underdeveloped tourism infrastructure (especially in the Romanian mountain area), the negative impact of human activities, the degradation of natural and cultural attractions, the unprofessional coordination and promotion.

For the future, a successful $\mathrm{CBC}$ in tourism areas should definitely consider moving from stand-alone investments and projects to integrated actions in rural tourism. It should encompass various natural and man-made attractions in rural packages and rural tourism destinations, well designed and able to enter into European or international competition. Another priority must be the development of an integrated promotion of the rural tourism at cross-border and euro-regional level. Finally, more significant and effective involvement of local communities, individuals and local businesses is needed, for developing joint programmes and more focus on economic performance and sustainability issues of the projects.

The CBC in Central and Eastern Europe is undoubtedly still far from drawing upon its full potential. Nonetheless, the results already achieved in a relatively short time period by the Hungarian-Romanian CBC programmes in the development of rural tourism are certainly positive and encouraging. 


\section{References}

Badulescu, D., Giurgiu, A., Istudor, N., Badulescu, A. 2015a 'Rural tourism development and financing in Romania: A supply-side analysis', Agric.Econ.Czech 61(2): 72-80.

Badulescu, D., Badulescu, A. \& Bucur, C.A. 2015b 'Considerations on the Effectiveness of Cross-Border Cooperation in Public Order and Civil Protection Services. The Case of the Romanian - Hungarian Border Area', Lex Localis-Journal of Local Self-Government 13(3): 559-578.

BRECO (Regional Office for Cross-border Cooperation for Romanian-Hungarian Border) 2015 Programme. Overview, Available: http://www.huro-cbc.eu/en/ overview/_(June 2015).

Briedenhann, J. \& Wickens, E. 2004 'Tourism Routes as a Tool for Local Economic Development of Rural Areas: Vibrant Hope or Impossible Dream?', Tourism Management 25: 71-79.

Brown, F. \& Hall, D. 2000 Tourism in Peripheral Areas, Clevedon: Channel View Publications.

Cawley, M., Marsat, J. \& Gillmor, D. 2007 'Promoting integrated rural tourism: comparative perspectives on institutional networking in France and Ireland, Tourism Geographies 9(4): 405-420.

Council of Europe 2006 Practical Guide to Transfrontier Cooperation, Mission Opérationnelle Transfrontalière.

European Commission (EC) 2014 CAP Context Indicators. 30: Tourism Infrastructure, Agriculture and Rural Development.

Eurostat 2013 'Chapter 15. Focus on rural development' in: Regional yearbook 2013, Luxembourg: Publications Office of the European Union, pp. 238-262.

Eurostat 2015 Capacity and occupancy of tourist accommodation establishments, Available: at http://appsso.eurostat.ec.europa.eu/nui/show.do?dataset=tour_occ_ ninatd\&amp;lang=en (June 2017).

Hall, D. 1998 'Tourism development and sustainability issues in central and southeastern Europe', Tourism Management 19(5): 423-431.

Hegarty, C. \& Przezborska, L. 2005 'Rural and Agri-Tourism as a Tool for Reorganising Rural Areas in Old and New Member States - a Comparison Study of Ireland and Poland', International Journal of Tourism Research 7: 63-77.

Hungarian Central Statistical Office 2014 Times series of annual, regional statistics Economic branches. Available: http://www.ksh.hu/stadat_annual_6_42 (July 2015).

Hungary-Romania Cross-Border Co-operation Programme 2007-2013, 2015 Overwiew. Availabl: http://www.huro-cbc.eu/en/overview/ (July 2015). 
Joint Working Group (JWG) RO HU 2015. Cooperation Programme Document. Interreg V-A Romania-Hungary. Available: http://www.mdrt.ro/userfiles/SEA_ INTERREG/CP_ROHU_for_Governmental_approval.pdf (August 2015).

Kostopoulou, S., Kourkouridis, D. \& Xanthopoulou-Tsitsoni, V. 2015 'Rural Tourism Development and Cross-border Cooperation: Networking Local Products Festivals', Journal of Tourism Research 10: 82-89.

Lane, B. 1994 'What is Rural Tourism?', Journal of Sustainable Tourism 1\&2(18): 7-21.

MEGAKOM Development Consultants, KPMG Advisory Ltd. and ICG Ex Ante 2014 Strategic planning based on the analysis of the eligible programme area of Hungary-Romania CBC Programme.

National Institute of Statistics (Romania) 2013 Statistical yearbook 2013 - Tourism, Available: http://www.insse.ro/cms/files/Anuar\%20statistic/20/20\%20Turism_ ro.pdf, (August 2015).

Perkmann, M. 2007 'The rise of the Euroregion. A bird's eye perspective on European cross-border co-operation', Department of Sociology, Lancaster University, Available: http://www.comp.lancs.ac.uk/sociology/papers/Perkmann-Rise-ofEuroregion.pdf (August 2015).

Petrou, A., Pantziou, E., Dimara, E. \& Skuras, D. 2007 'Resources and activities complimentarities: the role of business networks in the provision of integrated rural tourism, Tourism Geographies 9(4): 421-440.

Reed, M. G. 1999 'Collaborative tourism planning as adaptive experiments in emergent tourism settings', Journal of Sustainable Tourism 7: 331-355.

Slee, B., Farr, H. \& Snowdon, P. 1997 'The Economic Impact of Alternative Types of Rural Tourism, Journal of Agricultural Economics 48(2): 179-192.

Wanhill, S. 1977 'Peripheral area tourism: an European perspective', Progress in Tourism and Hospitality Research 3: 47-70. 


\begin{tabular}{|c|c|c|c|c|c|c|c|c|}
\hline 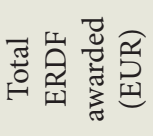 & $\begin{array}{l}\hat{n} \\
\hat{N} \\
\text { N }\end{array}$ & 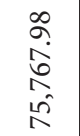 & 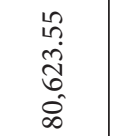 & 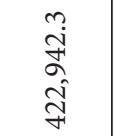 & 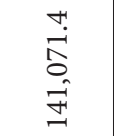 & $\begin{array}{l}\stackrel{0}{\stackrel{n}{n}} \\
\stackrel{-}{n}\end{array}$ & 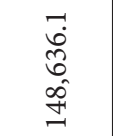 & 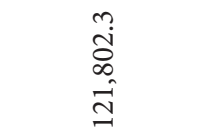 \\
\hline 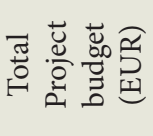 & 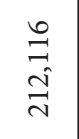 & $\begin{array}{l}\infty \\
\infty \\
m \\
\cdots \\
\infty\end{array}$ & 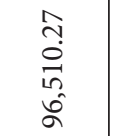 & $\begin{array}{l}n \\
2 \\
\hat{0} \\
n\end{array}$ & $\begin{array}{l}\stackrel{2}{\tilde{m}} \\
\stackrel{-}{=}\end{array}$ & 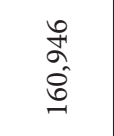 & 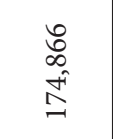 & $\begin{array}{l}\stackrel{8}{0} \\
\stackrel{1}{\infty} \\
\stackrel{\infty}{+} \\
=\end{array}$ \\
\hline 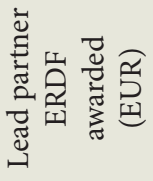 & $\begin{array}{l}\stackrel{+}{+} \\
\stackrel{+}{N} \\
\infty \\
\infty\end{array}$ & $\begin{array}{l}\hat{1} \\
\infty \\
\infty \\
\infty \\
0\end{array}$ & $\begin{array}{l}\hat{\sigma} \\
\text { ma } \\
\text { mे } \\
\hat{n}\end{array}$ & $\begin{array}{l}n \\
0 \\
0 \\
0 \\
2 \\
\end{array}$ & $\begin{array}{l}\text { 음 } \\
\text { जी }\end{array}$ & $\begin{array}{l}0 \\
\infty \\
+ \\
0 \\
\hat{i} \\
\hat{0}\end{array}$ & $\begin{array}{l}n \\
\hat{n} \\
\hat{\sigma} \\
0 \\
\infty\end{array}$ & 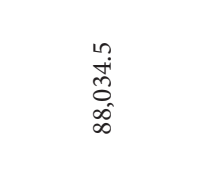 \\
\hline 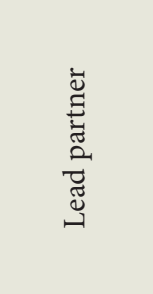 & 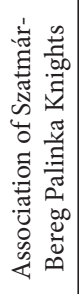 & 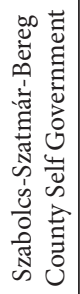 & 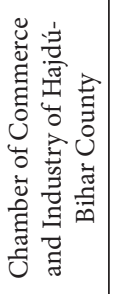 & 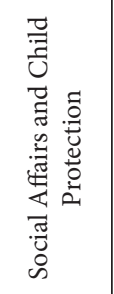 & 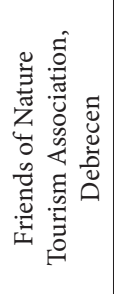 & 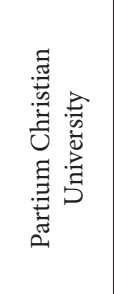 & 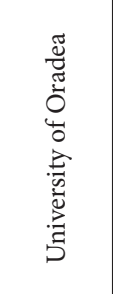 & 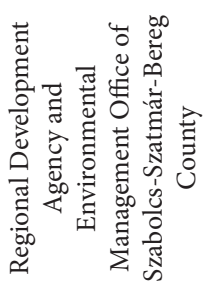 \\
\hline 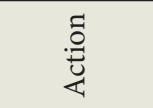 & $\stackrel{\dot{m}}{\vec{i}}$ & $\stackrel{\dot{n}}{\vec{i}}$ & $\underset{\vec{i}}{\stackrel{m}{i}}$ & $\underset{\vec{i}}{\stackrel{m}{i}}$ & $\stackrel{\dot{m}}{\vec{i}}$ & $\overrightarrow{\text { m.j}}$ & $\stackrel{n}{i}$ & $\stackrel{\dot{m}}{\vec{i}}$ \\
\hline$\stackrel{\text { 芒 }}{E}$ & 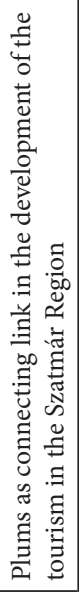 & 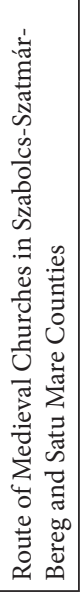 & 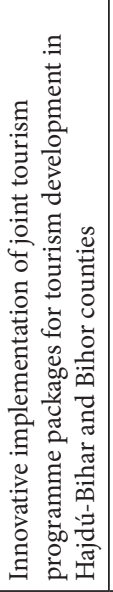 & 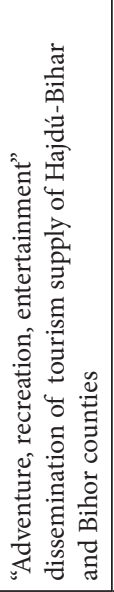 & 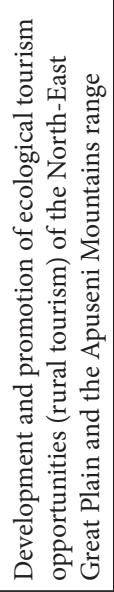 & 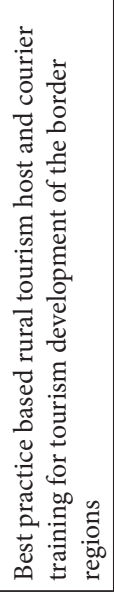 & 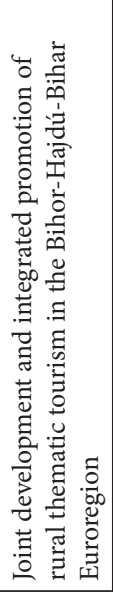 & 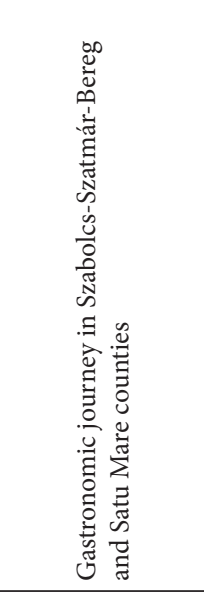 \\
\hline 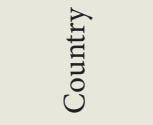 & 至 & 出 & 圭 & 可 & 号 & $\stackrel{\text { }}{\simeq}$ & 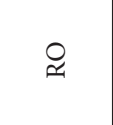 & 圭 \\
\hline$\dot{z}$ & $\neg$ & $N$ & $m$ & H & in & 6 & $\Lambda$ & $\infty$ \\
\hline
\end{tabular}




\begin{tabular}{|c|c|c|c|c|c|c|c|c|c|c|}
\hline 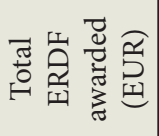 & $\begin{array}{l}n \\
0 \\
0 \\
m \\
\infty \\
0 \\
n \\
n\end{array}$ & 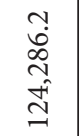 & $\begin{array}{l}\infty \\
\hat{0} \\
\hat{\sigma} \\
\therefore \\
\infty \\
\infty\end{array}$ & $\begin{array}{l}\vec{H} \\
\text { ה̃ } \\
\text { ñ } \\
\end{array}$ & 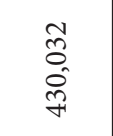 & 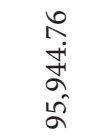 & $\begin{array}{l}\text { Lे } \\
\text { +ీ} \\
\text { त̂ }\end{array}$ & $\begin{array}{l}m \\
\stackrel{3}{\sharp} \\
0 \\
0 \\
0\end{array}$ & 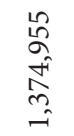 & 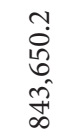 \\
\hline 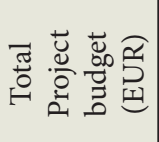 & $\begin{array}{l}\hat{\tilde{\sigma}} \\
\hat{\Omega} \\
\Omega\end{array}$ & 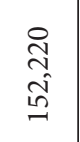 & 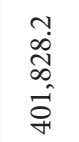 & 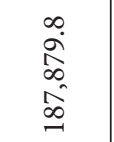 & $\begin{array}{l}\text { ते } \\
\text { ஸे } \\
\text { ڤn }\end{array}$ & $\begin{array}{l}\hat{n} \\
\hat{n} \\
\hat{n} \\
=\end{array}$ & 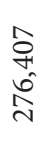 & \begin{tabular}{l}
$\infty$ \\
\multirow{1}{*}{} \\
$\infty$ \\
$\infty$ \\
$\wedge$
\end{tabular} & $\begin{array}{l}n \\
2 \\
2 \\
\hat{2} \\
\hat{-}\end{array}$ & 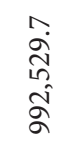 \\
\hline 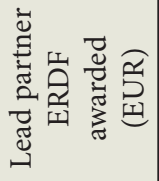 & \begin{tabular}{l}
$n$ \\
10 \\
$n$ \\
$n$ \\
0 \\
$\infty$ \\
\multirow{1}{n}{}
\end{tabular} & 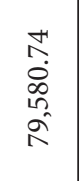 & 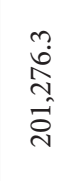 & 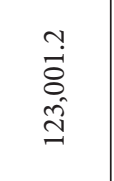 & $\begin{array}{l}\frac{i n}{+1} \\
\text { in } \\
\text { N } \\
\text { N }\end{array}$ & 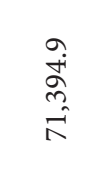 & $\begin{array}{l}\stackrel{-}{\dot{m}} \\
\stackrel{\vec{f}}{ \pm}\end{array}$ & 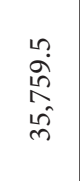 & 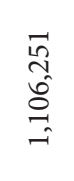 & 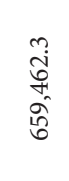 \\
\hline 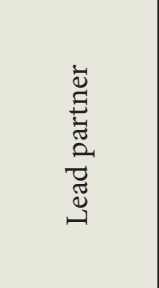 & 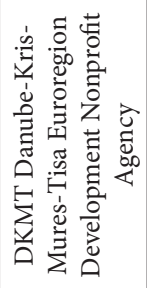 & 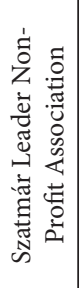 & 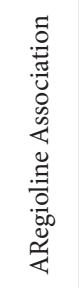 & 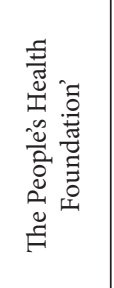 & 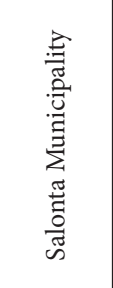 & 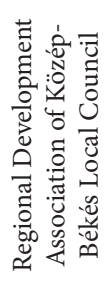 & 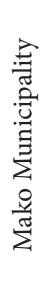 & 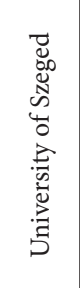 & 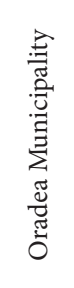 & 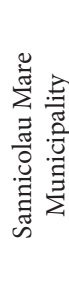 \\
\hline 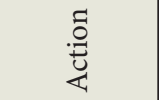 & $\stackrel{\dot{m}}{\stackrel{i}{i}}$ & $\stackrel{\ddot{n}}{\stackrel{i}{i}}$ & $\stackrel{\ddot{n}}{\stackrel{i}{i}}$ & $\stackrel{\dot{m}}{\stackrel{i}{i}}$ & $\stackrel{\vec{i}}{\vec{i}}$ & $\stackrel{\dot{m}}{\vec{i}}$ & $\underset{\dot{i}}{\stackrel{\dot{r}}{i}}$ & 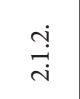 & $\stackrel{\dot{\sim}}{\vec{\sim}}$ & $\stackrel{\dot{m}}{\stackrel{i}{i}}$ \\
\hline$\stackrel{⿱}{\stackrel{\Xi}{E}}$ & 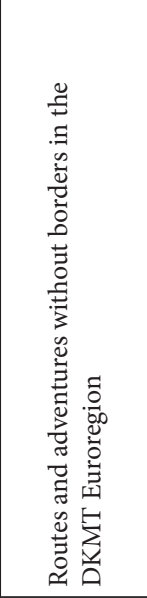 & 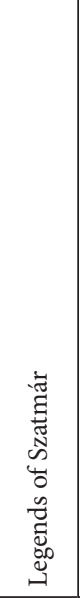 & 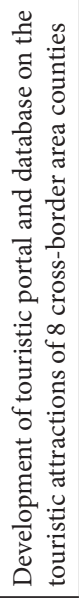 & 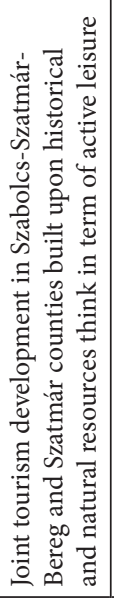 & 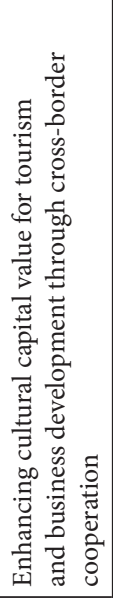 & 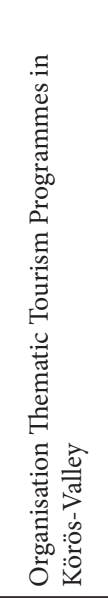 & 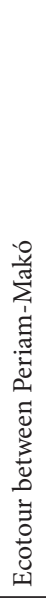 & 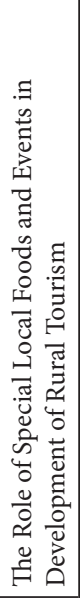 & 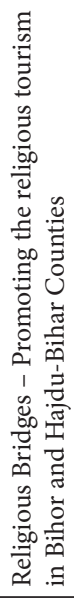 & 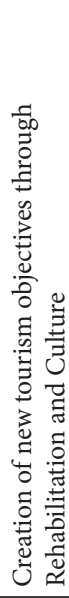 \\
\hline 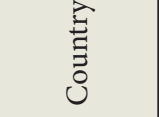 & 出 & 胥 & $\approx$ & 焉 & $\stackrel{\text { }}{\text { }}$ & 丞 & 足 & 疋 & $\stackrel{0}{\simeq}$ & $\stackrel{\circ}{\simeq}$ \\
\hline$\stackrel{\circ}{z}$ & $a$ & 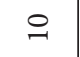 & $\exists$ & $\simeq$ & 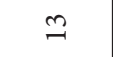 & 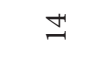 & $\stackrel{2}{2}$ & - & $\approx$ & 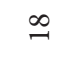 \\
\hline
\end{tabular}




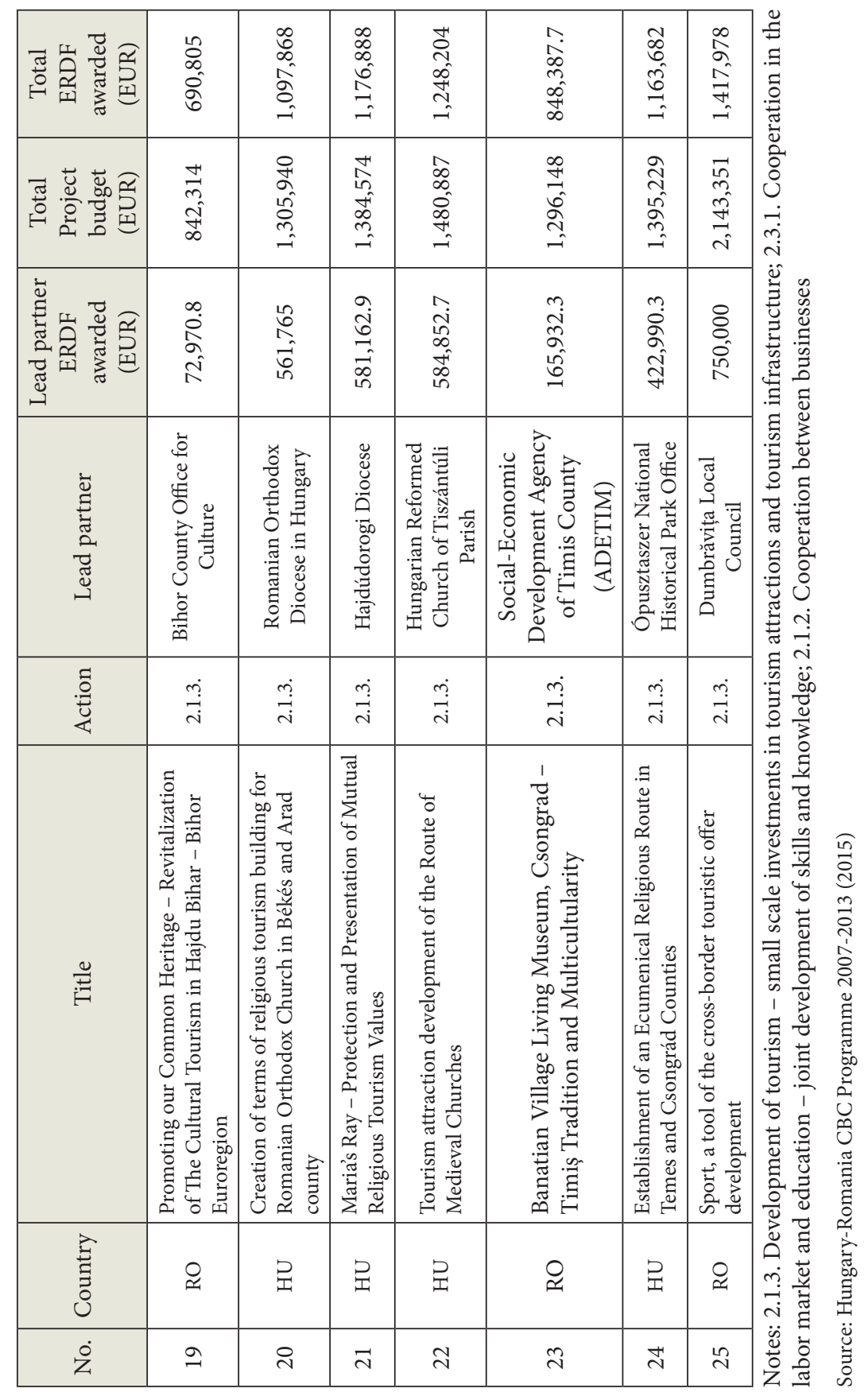

